Original Research Paper

\title{
Kondisi Eksisting Fauna Megabenthos di Perairan Labuhan Pandan Lombok Timur Pasca Gempa Bumi Lombok 7.0 Skala Richter
}

\author{
Noar Muda Satyawan ${ }^{*}$, Novita Tri Atriningrum ${ }^{1}$ \\ ${ }^{1}$ Program Studi Pemanfaatan Sumberdaya Perikanan Fakultas Perikanan Universitas 45 Mataram, Indonesia
}

\author{
Riwayat artikel \\ Received : 29 Juli 2019 \\ Revised : 26 September 2019 \\ Accepted : 27 September 2019 \\ Published : 28 September 2019 \\ *Corresponding Author: \\ Noar Muda Satyawan, \\ Program Studi Pemanfaatan \\ Sumberdaya Perikanan, \\ Fakultas Perikanan Universitas \\ 45 Mataram, Mataram, \\ Indonesia \\ Email: \\ satyawan.nm@gmail.com
}

\begin{abstract}
Abstrak : Gangguan eksternal pada ekosistem terumbu karang dapat terjadi secara alami ataupun karena aktifitas manusia yang menimbulkan perubahan fisik maupun ekologis. Perubahan ekologis dapat terlihat dari perubahan komposisi biota yang berasosiasi di dalamnya. Salah satu kelompok biota yang berasosiasi dengan terumbu karang adalah megabenthos. Tujuan dari penelitian ini adalah untk mengetahui kondisi eksisting fauna megabenthos pada ekosistem terumbu karang di perairan Labuhan Pandan Lombok Timur. Pengamatan dilakukan pada 5 stasiun yaitu Gili Bidara (BDR_01), Gili Kondo (KND_01), Gili Petagan 1 (PTG_01), Gili Petagan 2 (PTG_02), dan Gili Petagan 3 (PTG_03). Pengambilan data megabenthos dilakukan dengan metode Benthos Belt Transect (BBT). Hasil penelitian menunjukkan bahwa ditemukan 15 jenis megabenthos yang termasuk dalam 5 Phylum (Mollusca, Echinodermata, Chordata, Annelida, dan Platyhelminthes). Jumlah jenis tertinggi ditemukan pada phylum Echinodermata (10 jenis), kemudian diikuti oleh Mollusca ( 2 jenis), Chordata (1 jenis), Annelida (1 jenis), dan Platyhelminthes (1 jenis). Kepadatan megabenthos tertinggi ditemukan pada stasiun BDR_01 (10.571 ind/Ha), kemudian diikuti oleh stasiun KND_01 (10.214 ind/Ha), PTG_02 (9.857 ind/Ha), PTG_03 (8.429 ind/Ha) dan PTG_01 (1.714 ind/Ha). Keanekaragaman jenis tertingi ditemukan pada stasiun PTG_01 $\left(\mathrm{H}^{\prime}=1,14\right)$, kemudian diikuti oleh BDR_01 $\left(\mathrm{H}^{\prime}=0,76\right)$, KND_01 $\left(\mathrm{H}^{\prime}=0,69\right)$, PTG_03 $\left(\mathrm{H}^{\prime}=0,17\right)$ dan PTG_02 $\left(\overline{\mathrm{H}}^{\prime}=0,09\right)$. Hasil perhitungan indeks dominansi menunjukkan bahwa Didemnum molle (phylum Chordata) ditemukan dominan pada seluruh stasiun pengamatan. Ditemukan juga jenis megabenthos pemangsa hewan karang yaitu Acanthaster planci pada stasiun PTG_03 serta Drupella sp. pada stasiun BDR_01, KND_01 dan PTG_02. Beberapa jenis megabenthos yang ditemukan dapat dijadikan bioindikator dalam pemantauan kesehatan ekosistem terumbu karang di Perairan Labuhan Pandan, Lombok Timur.
\end{abstract}

Kata Kunci: Kondisi eksisting, Megabenthos, Gempa Bumi, Labuhan Pandan, Lombok Timur

Abstract: External disturbance to the coral reef ecosystem occured by naturally or due to human activities that cause physical and ecological changes. Ecological changes could be seen from changes in the composition of the associated biota. One of the biota groups that associated with coral reefs were megabenthos. The purpose of this study were to determine the condition of the megabenthos fauna on coral reef ecosystems in the Labuhan Pandan waters, Eastern Lombok. Observations were made at 5 stations namely Gili Bidara (BDR_01), Gili Kondo (KND_01), Gili Petagan 1 (PTG_01), Gili Petagan 2 (PTG_02), and Gili Petagan 3 (PTG_03). Data of Megabenthos were collected by Benthos Belt Transect (BBT) method. The results showed that found 15 species of megabenthos included in 5 phylum (Mollusca, Echinoderm, Chordata, Annelida, and Platyhelminthes). The highest number of species were found in Echinoderms phylum (10 species), followed by Mollusca ( 2 species), 
Chordata ( 1 species), Annelida (1 species), and Platyhelminthes (1 species). The highest megabenthos density were found at BDR_01 station (10,571 ind / $\mathrm{Ha})$, then followed by stations KND_01 (10,214 ind / Ha), PTG_02 (9,857 ind / Ha), PTG_03 (8,429 ind / Ha) and PTG_01 (1,714 ind / Ha). The highest species diversity were found at stations PTG_01 $\left(\mathrm{H}^{\prime}=1.14\right)$, then followed by BDR_01 $\left(\mathrm{H}^{\prime}=0.76\right), \mathrm{KND} \_01(\mathrm{H} '=0.69)$, PTG_03 $\left(\mathrm{H}^{\prime}=0.17\right)$ and PTG_02 $\left(\mathrm{H}^{\prime}=0.09\right)$. The calculation result of dominance index shows that Didemnum molle (phylum Chordata) were found dominant in all observation stations. Also found species of coral predator Acanthaster planci at PTG_03 station and Drupella sp. at stations BDR_01, KND_01 and PTG_02. Several species of megabenthos can be used as bioindicators to monitoring of coral reef health in Labuhan Pandan Waters, Eastern Lombok.

Keywords: Existing conditions, megabenthos, earthquake, Labuhan Pandan, Eastern Lombok

\section{Pendahuluan}

Ekosistem terumbu karang di kawasan Kabupaten Lombok Timur, selain menghadapi tekanan dari aktivitas penangkapan ikan yang tidak ramah lingkungan serta aktivitas pariwisata yang tinggi juga harus menghadapi ancaman kerusakan secara alami. Salah satu ancaman yang terjadi secara alami saat ini adalah gempa bumi. Gempa bumi merupakan faktor fisika yang sedang terjadi beberapa pekan ini di lokasi tersebut. Episentrum gempa yang sangat dekat dengan Labuhan Pandan mengakibatkan kerusakan yang serius pada bangunan masyarakat setempat.

Selayaknya bangunan yang dibangun oleh manusia, terumbu karang juga memiliki struktur keras yang dibangun dari kalsium karbonat $\left(\mathrm{CaCO}_{3}\right)$. Gempa besar 7,0 SR yang mengguncang Pulau Lombok dikhawatirkan tidak hanya merusak bangunan di daratan namun juga berpotensi merusak struktur terumbu karang yang ada di perairan Lombok Timur khususnya Labuhan Pandan yang berjarak sangat dekat dengan episentrum gempa.

Gangguan eksternal baik yang terjadi secara alami ataupun karena aktifitas manusia akan menimbulkan perubahan pada kondisi ekosistem terumbu karang. Perubahan yang terjadi tidak hanya bisa dilihat dari perubahan fisik terumbu karang itu sendiri namun juga bisa dilihat secara ekologis, terutama dari biota yang berasosiasi dengan terumbu karang. Faktor ekologis yang berpengaruh terhadap pemulihan atau kerusakan terumbu karang adalah keseimbangan biologi dan keanekaragaman dalam ekosistem terumbu karang, seperti sistem rantai makanan dari predator dan mangsa serta grazer yang berasosiasi dan berperan penting dalam membentuk struktur terumbu karang (Castro \& Huber 2007).

Perubahan kondisi ekosistem terumbu karang tentunya akan memicu perubahan pada biota asosiasinya.
Salah satu kelompok biota yang berasosiasi dengan terumbu karang adalah megabenthos. Kerusakan terumbu karang akan memicu tumbuhnya jenis biota megabenthos yang dominan sesuai dengan kondisi perairan sehingga biota ini memiliki potensi sebagai bioindikator kondisi ekosistem terumbu karang. Oleh karena itu, pemantauan kondisi eksisting biota megabenthos di perairan Labuhan Pandan penting dilakukan untuk mengetahui perubahan kondisi terumbu karang pasca gempa bumi 7,0 SR yang melanda Pulau Lombok.

\section{Bahan dan Metode}

\section{Waktu dan Lokasi Penelitian}

Pemantauan kondisi eksisting fauna megabenthos dilakukan pada bulan Maret 2019 di perairan Labuhan Pandan, Kabupaten Lombok Timur. Pengambilan data dilakukan pada 5 stasiun pengamatan yaitu Gili Bidara 1 (BDR_01),Gili Kondo 1 (KND_01),Gili Petagan 1 (PTG_01),Gili Petagan 2 (PTG_02) dan Gili Petagan 3 (PTG_03).Peta lokasi penelitian disajikan pada Gambar 1 .

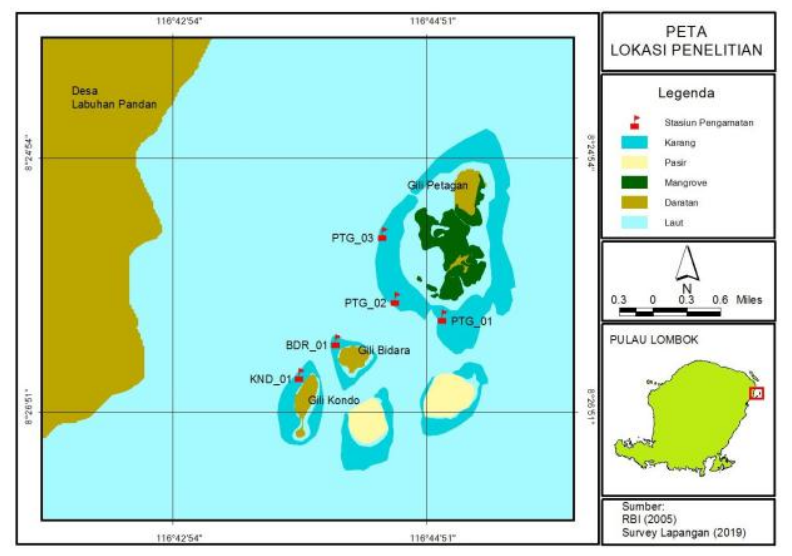

Gambar 1. Peta Lokasi Penelitian 


\section{Pengambilan data megabenthos}

Pengambilan data dilakukan dengan menggunakan bantuan peralatan selam SCUBA. Pengambilan data untuk monitoring megabenthos dilakukan dengan menggunakan metode Benthos Belt Transect (BBT). Transect dibuat spanjang 70 meter sejajar garis pantai dan pada kedalaman yang sama (7 - 12 meter). Pengamatan megabenthos dilakukan pada rentang 1 meter ke kiri dan 1 meter ke kanan garis transek. Semua jenis megabentos yang masuk dalam area pengamatan dicatat pada slide dan kemudian diinput dan dilakukan pengolahan data dengan bantuan Microsoft Excel.

\section{Pengolahan data megabenthos}

Adapun pengolahan data megabenthos yang dilakukan adalah sebagai berikut:

\section{a. Kepadatan megabenthos}

Kepadatan jenis megabenthos dianalisis menggunakan rumus beriktu:

$$
K=\frac{\text { Jumlah individu jenis }}{\text { Luas Belt Transect }\left(140 \mathrm{~m}^{2}\right)}
$$

Hasil analsisi kepadatan dikonversi ke dalam satuan hektar (Ha).

\section{b. Keanekaregaman jenis megabenthos}

Pengolahan data keanekaragaman menggunakan indeks keanekaragaman Shannon-Wiener (Krebs 1999) sebagai berikut:

Keterangan:

$$
H^{\prime}=-\sum p i \operatorname{LN} p i
$$

$$
\begin{array}{ll}
\mathrm{H}^{\prime} & \text { : Indeks Keanekaragaman Shanoon-Wiener } \\
\mathrm{Pi} & \text { : Jumlah individu jenis ke-i (ni) / Jumlah total } \\
& \text { individu }(\mathrm{N})
\end{array}
$$

\section{c. Indeks dominansi jenis megabenthos}

Indeks dominansi digunakan untuk memperoleh informasi mengenai jenis megabenthos yang dominan pada suatu komunitas. Untuk menentukan indeks dominansi jenis megabenthos merujuk pada Simpson (1949) dalam Odum (1971) yaitu:

$$
D i=\frac{n i}{N} \times 100 \%
$$

Keterangan:

Di : Dominansi jenis megabenthos

ni : Jumlah individu jenis ke-i

$\mathrm{N} \quad$ : Jumlah total individu

Kriteria dominansi jenis merujuk pada Torgensen \& Baxter (2006) yaitu: Dominan jika Di > 50\%; Subdominan (umum) jika Di 10 - 50\%; Tidak dominan (jarang) jika Di $<10 \%$.

\section{Hasil dan Pembahasan}

\section{Kepadatan jenis megabenthos}

Gempa besar yang melanda Pulau Lombok beberapa bulan yang lalu telah menimbulkan dampak kerugian personil dan meteriil yang tidak sedikit. Guncangan yang ditimbulkan meruntuhkan bangunan masyarakat yang berada di sekitar episentrum gempa. Dampak tersebut dihawatirkan tidak hanya terjadi didaratan namun juga terjadi didasar perairan. Pemantauan kondisi terumbu karang sangat diperlukan untuk mengetahui sejauh mana dampak yang ditimbulkan oleh gangguan fisika seperti gempa bumi terhadap ekosistem terumbu karang. Salah satu kelompok biota yang dijadikan indikator perubahan kondisi ekosistem terumbu karang adalah megabenthos.

Megabenthos selain berperan penting dalam siklus nutrien dan produsen sekunder dalam perairan, kelompok organisme ini juga berperana prnting dalam menyokong rantai makanan dalam eosistem sebagai makanan untuk ikan demersal dan mamalia laut ( Kronck and Reiss 2010; Tabatabaien and Amiri 2011; Sahidin dan Wardiatno 2016). Satyawan et al. (2013) melaporkan bahwa laju erosi kalsium karbonat $\left(\mathrm{CaCO}_{3}\right)$ juga disebabkan oleh akifitas makan bulu babi peliang pada kawasan terumbu karang Pulau Okinawa.

Perubahan fisika, kimia dan biologi merupakan indikator penentuan kualitas perairan (Sharma et al. 2018). Pergerakan megabenthos sangat terbatas dan relatif menetap pada substrat membuat megabenthos menjadi lebih sensitif terhadap perubahan lingkungan perairan (Manoharan et al. 2011; Wardiatno et al. 2017). Keberadaan megabenthos sangat bergantung pada karakteristik perairan seperti perbedaan temperatur, salinitas dan tipe substrat dasar perairan (Shou et al. 2009; Gholizadeh et al. 2012). Perubahan kondisi dan komposisi substrat dasar perairan akan memicu perubahan pada komposisi megabenthos yang ada didalamnya sehingga megabenthos sering digunakan sebagai bioindikator dalam penentuan kondisi suatu perairan (Dean 2008; Shokat et al. 2010; Sharma et al. 2018). 
Tabel 1. Jumlah individu dan kepadatan megabenthos pada masing-masing stasiun penagamatan

\begin{tabular}{|c|c|c|c|c|c|c|c|c|c|c|c|c|}
\hline \multirow[b]{2}{*}{ Phylum } & \multirow[b]{2}{*}{ No. } & \multirow[b]{2}{*}{ Species } & \multicolumn{2}{|c|}{ BDR_01 } & \multicolumn{2}{|c|}{ KND_01 } & \multicolumn{2}{|c|}{ PTG_01 } & \multicolumn{2}{|c|}{ PTG_02 } & \multicolumn{2}{|c|}{ PTG_03 } \\
\hline & & & Jml & $\underset{\left(\operatorname{Ind} / \mathrm{m}^{2}\right)}{\mathrm{K}}$ & $\mathrm{Jml}$ & $\begin{array}{c}\mathrm{K} \\
\left(\operatorname{Ind} / \mathrm{m}^{2}\right)\end{array}$ & Jml & $\underset{\left(\mathrm{Ind} / \mathrm{m}^{2}\right)}{\mathrm{K}}$ & Jml & $\underset{\left(\operatorname{Ind} / \mathrm{m}^{2}\right)}{\mathrm{K}}$ & Jml & $\begin{array}{c}\mathrm{K} \\
\left(\mathrm{Ind} / \mathrm{m}^{2}\right)\end{array}$ \\
\hline \multirow[t]{2}{*}{ Mollusca } & 1 & Drupella sp. & 11 & 0,08 & 2 & 0,01 & 0 & 0,00 & 1 & 0,01 & 0 & 0,00 \\
\hline & 2 & Cypraea tigris & 3 & 0,02 & 0 & 0,00 & 0 & 0,00 & 0 & 0,00 & 0 & 0,00 \\
\hline \multirow[t]{10}{*}{$\begin{array}{l}\text { Echino- } \\
\text { dermata }\end{array}$} & 3 & $\begin{array}{l}\text { Linckia } \\
\text { laevigata }\end{array}$ & 10 & 0,07 & 6 & 0,04 & 2 & 0,01 & 1 & 0,01 & 0 & 0,00 \\
\hline & 4 & Fromia monilis & 1 & 0,01 & 0 & 0,00 & 0 & 0,00 & 0 & 0,00 & 0 & 0,00 \\
\hline & 5 & $\begin{array}{l}\text { Acanthaster } \\
\text { planci }\end{array}$ & 0 & 0,00 & 0 & 0,00 & 0 & 0,00 & 0 & 0,00 & 1 & 0,01 \\
\hline & 6 & $\begin{array}{l}\text { Echinothrix } \\
\text { calamaris }\end{array}$ & 1 & 0,01 & 0 & 0,00 & 0 & 0,00 & 0 & 0,00 & 0 & 0,00 \\
\hline & 7 & $\begin{array}{l}\text { Echinothrix } \\
\text { diadema }\end{array}$ & 0 & 0,00 & 0 & 0,00 & 3 & 0,02 & 0 & 0,00 & 0 & 0,00 \\
\hline & 8 & $\begin{array}{l}\text { Diadema } \\
\text { savignyi }\end{array}$ & 0 & 0,00 & 0 & 0,00 & 1 & 0,01 & 0 & 0,00 & 0 & 0,00 \\
\hline & 9 & $\begin{array}{l}\text { Synapta } \\
\text { maculata }\end{array}$ & 1 & 0,01 & 0 & 0,00 & 0 & 0,00 & 0 & 0,00 & 0 & 0,00 \\
\hline & 10 & $\begin{array}{l}\text { Pearsonothuria } \\
\text { graffaei }\end{array}$ & 1 & 0,01 & 0 & 0,00 & 1 & 0,01 & 0 & 0,00 & 0 & 0,00 \\
\hline & 11 & $\begin{array}{l}\text { Comaster } \\
\text { schlegelii }\end{array}$ & 0 & 0,00 & 15 & 0,11 & 0 & 0,00 & 0 & 0,00 & 3 & 0,02 \\
\hline & 12 & $\begin{array}{l}\text { Ophioderma } \\
\text { brevispinum }\end{array}$ & 0 & 0,00 & 1 & 0,01 & 0 & 0,00 & 0 & 0,00 & 0 & 0,00 \\
\hline Chordata & 13 & $\begin{array}{l}\text { Didemnum } \\
\text { molle }\end{array}$ & 120 & 0,86 & 117 & 0,84 & 16 & 0,11 & 136 & 0,97 & 114 & 0,81 \\
\hline Annelida & 14 & $\begin{array}{l}\text { Sabellastarte } \\
\text { sp. }\end{array}$ & 0 & 0,00 & 1 & 0,01 & 1 & 0,01 & 0 & 0,00 & 0 & 0,00 \\
\hline \multirow[t]{2}{*}{$\begin{array}{l}\text { Platyhel- } \\
\text { minthes }\end{array}$} & 15 & $\begin{array}{l}\text { Pseudoceros } \\
\text { imitatus }\end{array}$ & 0 & 0,00 & 1 & 0,01 & 0 & 0,00 & 0 & 0,00 & 0 & 0,00 \\
\hline & \multicolumn{2}{|c|}{ Jumlah } & 148 & & 141 & & 23 & & 138 & & 118 & \\
\hline
\end{tabular}

Berdasarkan hasil pengamatan diperoleh data jenis dan jumlah individu megabenthos di perairan Labuhan Pandan. Tabel 1 menunjukkan bahwa ditemukan 15 jenis megabenthos yang termasuk ke dalam 5 Phylum yaitu Mollusca, Echinodermata, Chordata, Anellida dan Platyhelminthes. Phylum Echinodermata memiliki jumlah jenis terbanyak yaitu 10 jenis kemudian diikuti oleh Mollusca (2 jenis), Chordata (1 jenis), Anellida (1 jenis) dan Platyhelminthes (1 jenis).

Dari 8 jenis megabenthos yang dijadikan terget pemantauan oleh COREMAP CTI - LIPI, ditemukan 5 jenis di perairan Labuhan Pandan yaitu Drupella sp., bintang laut (Linckia laevigata), Acanthaster planci, Bulu babi dan Teripang. Kima, siput lola dan lobster tidak ditemukan di kawasan terumbu karang perairan Labuhan Pandan. Disamping itu, kepadatan megabenthos target yang ditemukan lebih rendah dibandingkan dengan perairan lainya di Pulau Lombok. Bachtiar dkk. (2018) melaporkan bahwa kepadatan megabenthos target di perairan Teluk Sekotong mencapai 1012 individu/Ha.

Berdasarkan hasil pengolahan data diperoleh kepadatan jenis megabenthos pada masing-masing stasiun pengamatan (Gambar 2). Kepadatan tertinggi ditemukan di stasiun BDR_01 dengan 10.572 individu/Ha kemudian diikuti oleh KND_01 (10.214 individu/Ha), PTG_02 (9.857 individu/Ha), PTG_03 (8.429 individu/Ha) dan PTG_01 (1.714 individu/Ha). Didemnum molle merupakan jenis megabenthos yang memiliki kepadatan tertinggi pada seluruh stasiun pengamatan.

\section{Indeks Ekologi megabenthos}

Hasil analisis indeks keanekaragaman ShannonWiener diperoleh indeks keanekaragaman yang beragam pada masing-masing stasiun pengamatan (Gambar 3). Indeks keanekaragaman tertinggi ditemukan pada stasiun PTG_01 $\left(\mathrm{H}^{\prime}=1,14\right)$ kemudian diikuti oleh BDR_01 $\left(\mathrm{H}^{\prime}=\right.$ 
0,79), KND_01 $\left(\mathrm{H}^{\prime}=0,69\right)$, PTG_03 $\left(\mathrm{H}^{\prime}=0,17\right)$ dan PTG_02 $\left(\mathrm{H}^{\prime}=0,09\right)$. Nilai indeks keanekaragaman Shanoon-Wiener tersebut tergolong rendah dikarenakan adanya jenis megabenthos yang dominan dalam jumlah individu yang ditemukan.

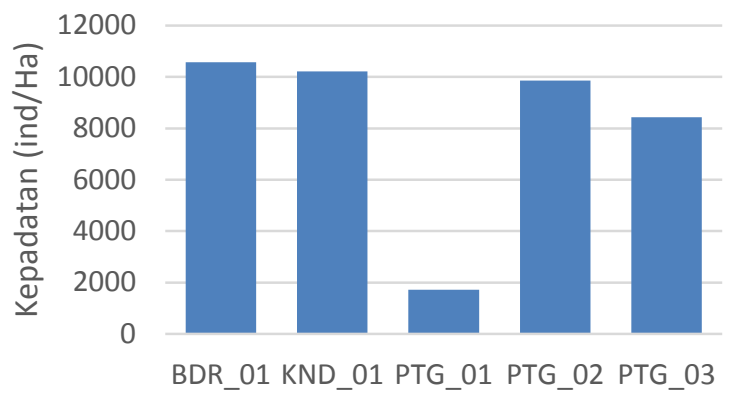

Gambar 2. Kepadatan megabenthos yang ditemukan pada masing-masing stasiun pengamatan

Indeks dominansi ditentukan berdasarkan indeks dominansi Simpson. Hasil pengolahan data menunjukkan bahwa ditemukan jenis yang mendominansi pada masingmasing stasiun pengamatan (Gambar 4). Didemnum molle (Filum Chordata) merupakan jenis yang dominan ditemukan pada seluruh stasiun. Biota diketahui memiliki sebaran luas yang umumnya ditemukan di perairan litoral mulai dari zona intertidal hingga sub tidal, menempel pada lambung kapal, kerang, cangkang moluska, dan pada substrat pasir dan lumpur. (Suwignyo $d k k$ 2005). Didemnidae merupakan jenis yang paling mendominasi di perairan dangkal tropis. Jenis Ascidian dari suku Didemnidae memiliki adaptasi yang tinggi terhadap kondisi perairan dan mampu bertahan hidup pada tipe habitat yang beragam (Abrar \& Manuputty 2008).

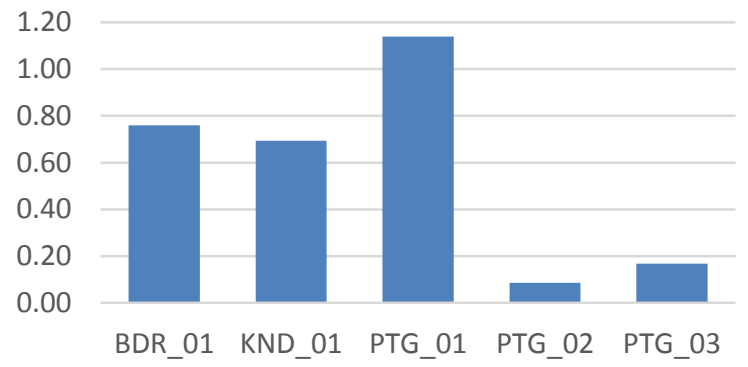

Gambar 3. Indeks Keanekaragaman jenis megabenthos pada masing-masing stasiun

Didemnum molle tergolong dalam kelompok Ascidian yang merupakan anggota dari kelas Ascidiaceae, yang meyusun hampir sebagian besar Filum Chordata (McClintock \& Baker 2001). Ascidian umunya tergolong dala organisme penempel dan banyak ditemukan pada ekosistem terumbu karang. Organisme ini merupakan penyaring air alami, tahan terhadap bermacam jenis polutan dan dapat menyaring bakteri dan logam berat dari air yang berbahaya bagi ekosistem terumbu karang (Erdman 2004).

Biota ini juga banyak mengandung senyawa bioaktif untuk farmakologi karena asosiasinya dengan mikroba fotosintetik. Warna hijau yang tampak pada Didemnum molle merupakan akibat dari simbiosisnya dengan alga hijau Prochloron (Hirose \& Maruyama 2004). Karena kandungan metabolit sekundernya yang merupakan substansi bioaktif biota ini banyak dimanfaatkan sebagai antitumor, antikanker, antibakteri dan antimikroba. Kossuga et al. (2009) Melaporkan bahwa senyawa bioaktif yang diekstrak dari genus Didemnum menunjukkan aktifitas antibiotik terhadap isolat klinis Streptococcus mutans dan Staphylococcus aureus.

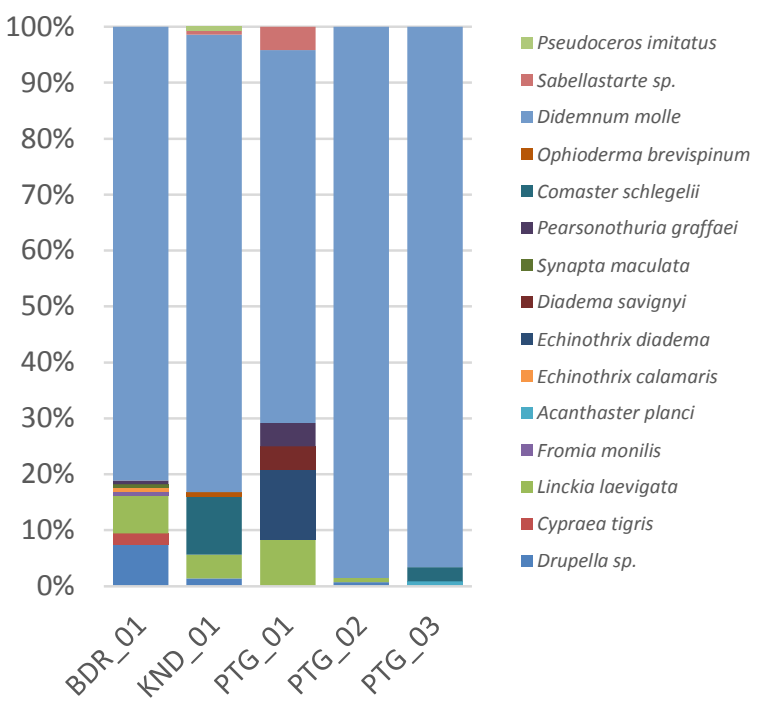

Gambar 4. Dominansi jenis megabenthos pada masingmasing stasiun pengamatan

Selain dari Filum Chordata dengan jumlah induvidu terbanyak, ditemukan juga jumlah jenis terbanyak yang berasal dari Filum Echinodermata (10 jenis). Jumlah jenis Echinodermata yang ditemukan di perairan Labuhan Pandan lebih rendah bila dibandingkan dengan lokasi lainnya di Pulau Lombok. Satyawan dkk. (2014) menemukan 20 jenis megabenthos dari Filum Echinodermata pada zona terumbu karang Pantai Semerang, Lombok Timur. Yusron (2010) menemukan 12 jenis Echinoderata di Tanjung Kayangan, 12 jenis di pantai Medana, dan 11 jenis di Teluk Kuta. Anggota dari Filum Echinodermata memegang peranan penting dalam menjaga rantai makanan dan siklus nutrien pada ekosistem terumbu karang (Satyawan et al., 2013).

\section{Megabenthos sebagai bioindikator}

Salah satu jenis megabenthos yang perlu dipantau keberadaannya dalam ekosistem terumbu karang adalah 
Drupella sp (Gambar 5a). Jenis ini merupakan anggota dari filum moluska, kelas Gastropoda dan famili Muricidae. Drupella merupakan siput pemangsa polip karang sehingga keberadaannya sangat tergantung pada kondisi terumbu karang yang dijadikan tempat mencari makan bagi organisme tersebut. Kepadatan Drupella yang ditemukan di perairan Labuhan Pandan berkisar antara $0,01-0,08$ individu $/ \mathrm{m}^{2}$. Kepadatan tertinggi ditemukan pada stasiun BDR_01. Lalang dkk. (2013) melaporkan bahwa kepadatan Drupella berkorelasi negatif dengan tutupan karang hidup sehingga jarang ditemukan pada jaringan karang hidup dan cenderung menjauhi area yang belum dimakan agar terhindar dari sel penyengat (nematocyst) hewan karang.
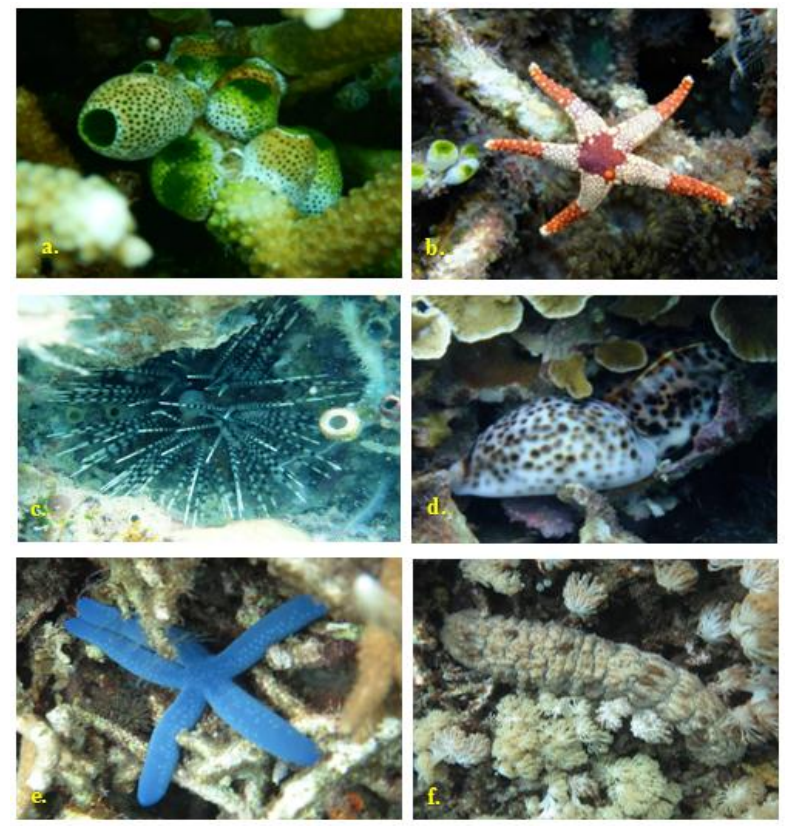

Gambar 4. Beberapa jenis megabenthos yang ditemukan di perairan Labuhan Pandan Lombok Timur (a. Didemnum molle; b. Fromia monilis; c. Echinothrix calamaris; d.Cypraea tigris; e. Linckia laevigata; f. Pearsonothuria graffaei)

Selain Drupella, jenis megabenthos yang juga merupakan pemangsa polip karang yang ditemukan di perairan Labuhan Pandan adalah Acanthaster planci (Gambar 5b). Organisme ini merupakan anggota dari Filum Echinodermata dari kelas Asteroidea. Jenis megabenthos ini ditemukan pada stasiun PTG_03. Jumlah yang ditemukan masih tergolong aman dan tidak mengancam keberadan terumbu karang. Ancaman akan muncul apabila populasi $A$. planci dalam ekosistem terumbu karang tidak terkontrol sehingga menimbulkan dampak yang negatif. Keberadaan A. planci dianggap mengancam terumbu karang bila ditemukan 14 individu/1000 $\mathrm{m}^{2}$ atau 0,014 individu/ $\mathrm{m}^{2}$ (Endean, 1987).
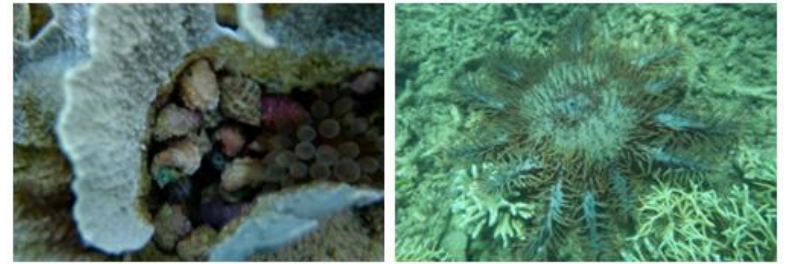

Gambar 5. Jenis megabenthos pemangsa polip karang yang ditemukan di perairan Labuhan Pandan Lombok Timur (a. Drupella sp. ; b. Acanthaster planci)

Pergerakan megabenthos sangat terbatas dan relatif menetap pada substrat sehingga kelompok organisme ini menjadi lebih sensitif terhadap perubahan lingkungan perairan. Perubahan kondisi dan komposisi substrat terumbu karang akan memicu perubahan pada komposisi megabenthos sehingga sering digunakan sebagai bioindikator untuk menentukan kondisi ekosistem terumbu karang. Berdasarkan data jenis megabenthos yang ditemukan, beberapa jenis diantaranya bisa dijadikan bioindikator yaitu Drupella sp., Echinothrix calamaris, Echinothrix Diadema, Diadema setosum, Linckia laevigata dan Acanthaster planci.

\section{Kesimpulan}

Berasarkan hasil penelitian dapat ditarik kesimpulan bahwa ditemukan 15 jenis megabenthos yang termasuk dalam 5 Phylum (Mollusca, Echinodermata, Chordata, Annelida, dan Platyhelminthes). Jumlah jenis tertinggi ditemukan pada phylum Echinodermata, kemudian diikuti oleh Mollusca, Chordata, Annelida, dan Platyhelminthes. Kepadatan megabenthos ditemukan beragam pada masing-masing stasiun pengamatan. Keanekaragaman jenis yang rendah menunjukkan adanya jenis yang dominan yaitu Didemnum molle. Ditemukan juga jenis megabenthos pemangsa polip karang yaitu Acanthaster planci dan Drupella sp. Beberapa jenis megabenthos yang ditemukan dapat dijadikan bioindikator dalam monitoring perubahan kondisi terumbu karang di perairan Labuhan Pandan.

\section{Ucapan Terima Kasih}

Ucapan terimakasih kami sampaikan kepada DRPM Kemenristek Dikti atas pendanaan yang diberikan sehingga penelitian ini dapat terlaksana dan diselesaikan tepat pada waktunya. Terimakasih juga kami sampaikan kepada Lembaga Penelitian dan Pengabdian Masyarakat Universitas 45 Mataram. Tidak lupa kami sampaikan terimakasih kepada pihak-pihak yang membantu dalam pengambilan data sampai terpublikasikannya hasil penelitian ini. 


\section{Daftar Pustaka}

Abrar, M \& A.E.W Manuputty. (2008). Inventarisasi dan Sebaran Biota Ascidian Di Terumbu Karang Perairan Berau, Kalimantan Timur. Oseanologi dan Limnologi di Indonesia, 34: 47-66.

Bachtiar I, Karnan, Santoso D, Japa L, Satyawan N.M., Atmanegara F.K. \& Iien H. (2018). Monitoring Kesehatan Terumbu Karang dan Ekosistem Terkait di Sekotong, Lombok Barat. COREMAPCTI. Jakarta: Lembaga Ilmu Pengetahuan Indonesia. Pp. 63

Dean HK. (2008). The use of polychaetes (Annelida) as indicator species of marine pollution: a review. Int J Trop Biol 56 (4): 11-38.

Endean, R. (1987). Acanthaster planci investation. In: Salvat B. (ed). Human Impact on Coral Reefs: Facts and Recommendations. Antenne Museum EPHE, French Polynesia, Australia.

Erdmann, A.M. (2004). Buku 2 Lautan : Panduan Sejarah Ekologi Taman Nasional Komodo. The Nature Conservancy Indonesia Coastal and Marine Program

Gholizadeh M, Yahya A, Talib A. \& Ahmad O. (2012). Effects of environmental factors on polychaete assemblage in Penang National Park, Malaysia. Word Academy of Sci Eng Technol J 6 (12): 752755.

Hirose, E \& Maruyama, T. (2004). What Are The Benefits In The Ascidian-Prochloron Symbiosis?. Endocytobiosis Cell Res.15: 51-62.

Kossuga, M.H., Lira, S.P., McHugh, S., Torres, Y.R., Lima, B.A., Goncalves, R., Veloso, K., Ferreira, A.G., Rocha, R.M. \& Berlinck, R.G.S. (2009). Antibacterial Modified Diketopiperazines from two Ascidians of the Genus Didemnum. J. Braz. Chem. Soc., 20 (4): 704-711.

Kroncke I. \& Reiss H. (2010). Influence of macrofauna long-term natural variability on benthic indices used in ecological quality assessment. Mar Pollut Bull 60 (1): 58-68.

Lalang, Sadarun, B. \& Haya, L. O. M. Y. (2013). Kelimpahan Drupella dan Kondisi Terumbu Karang di Perairan Maluku Mandike Selat Tiworo Kabupaten Muna, Sulawesi Tenggara. Jurnal Mina Laut Indonesia, 1 (1) : 12 - 22.
Manoharan J, Varadharajan D, Thilagavathi B. \& Priyadharsini S. (2011). Biodiversity and abundance of benthos along the South East Coast of India. Adv App Sci Res 2(6): 554-562.

McClintock, J.B \& B.J. Baker. (2001). Marine and Chemical Ecology. CRC Press. Boca Raton.

Odum, E. P. (1971). Fundamentals of Ecology. W. B. Saundres Company. Philadelphia.

Sahidin A, Wardiatno, Y. (2016). Spatial distribution of Polychaete at Tangerang coastal water, Banten Province. J Fish Mar 6 (2): 83-94.

Satyawan, N.M., Tutupoho, S., Wardiatno. Y. \& Tsuchiya, M. (2013). Feeding behaviour and bioerosion: the ecological role of the rock-boring urchin, Echinometra mathaei (de Blainville, 1825), in Okinawa reef flat. Aquatic Science \& Management, 1 (1): 10 - 16.

Satyawan, N.M., Wardiatno, Y. \& Kurnia, R. (2014). Keanekaragaman Spesies dan Zonasi Habitat Echinodermata di Perairan Pantai Semerang, Lombok Timur. Jurnal Biologi Tropis, 14 (2) : 83 -92 .

Sharma SD, Behera RR, Mohapatra U, Panda CR \& Nayak L. (2018). Effect of estuarine effluents on benthic faunal communities in relation to tidal dynamics of Dhamra estuary. J Pharm Life Sci 4 (2): 127-134

Shokat P, Nabavi1 SMB, Savari1 A. \& Kochanian P. (2010). Ecologicalquality of Bahrekan coast, by using biotic indices and benthic communities. Transit. Waters Bull 4 (1): 25-34

Shou L, Huang Y, Zeng J, Goa A, Liao Y \& Chen Q. (2009). Seasonal changes of macrobenthos distribution and diversity in Zhoushan sea area. Aquatic ecosystem health and management. 12 (1): 110-115.

Suwignyo, S., Widigdo, B., Wardiyatno, Y. \& Krisanti, M. (2005). Avertebrata Air Jilid 1. Penebar Swadaya. Jakarta

Tabatabaie T \& Amiri F. (2011). Evaluation of the impact of industrial sewage pollution on marine benthic communities. Journal of Water Supply: Res Technol-AQUA 60 (6): 364-374. 
Torgensen, C. E. \& Baxter C. V. (2006). Landscape Influences on Longitudinal Patterns of River Fishes: Spatially continous Analysis of FishHabitat Relationships. American Fisheries Society.

Yusron, E. (2010). Penelitian kajian diversitas biota laut di perairan Lombok dan sekitarnya, Nusa Tenggara Barat. Pusat Penelitian Oseanografi LIPI. Jakarta.

Wardiatno, Y., Qonita, Y., Mursalin, Zulmi R, Effendi H, Krisanti M,Mashar A, Hariyadi S, Hakim AA, Sahidin A, Widigdo B \& Nursiyamah S. (2017). Determining ecological status of two coastal waters in Western Java using macrozoobenthic community: A comparison between North Part and
South Part. IOP Conf Ser: Earth Environ Sci 54 (1): 01207 